\title{
Mid-Holocene changes in the geochemical and biotic conditions of an aquatic ecosystem, in Eastern Mediterranean
}

\author{
Michael Styllas ${ }^{1}$, Elias Dimitriou ${ }^{1, *}, K_{0}$ ostas Gritzalis ${ }^{2}$, Maria Koutsodimou ${ }^{2}$, Ioannis Karaouzas ${ }^{2}$, \\ Nikolaos Skoulikidis ${ }^{2}$ and Alexandra Gogou ${ }^{2}$ \\ ${ }^{1}$ Geoservice ltd, Eirinis 15 street, 55236, Panorama, Thessaloniki, Greece \\ ${ }^{2}$ Hellenic Centre for Marine Research. Athens-Sounio Avenue (46.7 km), P.O. Box712, P.C. 19013 Anavyssos, Attiki, Greece
}

Received: 3 October 2017; Accepted: 30 March 2018

\begin{abstract}
Mediterranean Temporary Ponds (MTPs) are unique and sensitive aquatic ecosystems that due to their hydrological characteristics constitute an ideal setting for the study of past environmental dynamics. A $176 \mathrm{~cm}$ core was retrieved from the littoral zone of Omalos MTP in Lefka Ori massif, to provide a general view of the processes that drove its Lateglacial and Holocene evolution. The sedimentary sequence is partitioned in two major units: (i) Unit II ( $\sim 17-4.7 \mathrm{ka} \mathrm{BP})$, characterized by the catchment-derived transport, allogenic deposition of fine, $\mathrm{Al}_{2} \mathrm{O}_{3}$-rich, sediments and endogenic deposition of clays, under overall anoxic and dry climatic conditions, and (ii) Unit I ( $\sim 4.7 \mathrm{ka}$ to present), characterized by increasing wetness, establishment of watershed, aquatic and herbaceous vegetation and by $\mathrm{SiO}_{2}$ dominated sedimentation under overall oxic conditions. The enrichment of $\mathrm{SiO}_{2}$ in the littoral sediments since the mid-Holocene, can be of clastic, aeolian and biogenic origin, but the undertaken analyses did not permit such distinction. The overall dryness of Unit II was interrupted between $\sim 14.7$ and $13 \mathrm{ka}$ BP by wet conditions, evidenced by the establishment of littoral vegetation. The transition to the mid-Holocene system reorganization, was expressed by peak values of $\mathrm{Al}_{2} \mathrm{O}_{3}, \mathrm{Fe}_{2} \mathrm{O}_{3}, \mathrm{~K}_{2} \mathrm{O}, \mathrm{MgO}$ and $\mathrm{Cr}_{2} \mathrm{O}_{3}$ and by the deposition of calcite under warm and dry conditions. The mid-Holocene ( 4.7 ka BP) period of Omalos MTP ecosystem disturbance, likely corresponds to the " $4.2 \mathrm{ka}$ mega drought event" widespread in the eastern Mediterranean region. The potential of MTP's sedimentary sequences in reconstructing past environmental conditions is emphasized.
\end{abstract}

Keywords: Mediterranean Temporary Ponds / sediment biogeochemistry / mid-Holocene drought / Omalos / Crete

\section{Introduction}

From the majority of sedimentary environments (glacial, alluvial, fluvial, lacustrine, coastal and marine) employed in the reconstructions of past environmental changes, temporary ponds have received scant attention. Temporary ponds are often remnants of larger water bodies, a physical transition that constitutes them as ideal settings for paleoenvironmental studies, due to the fact their aquatic phase is representative of winter hydrological and spring/summer evaporative conditions. The occurrence of cyclical hydrologic conditions makes temporary ponds unique ecosystems, their habitats supporting distinctive invertebrate fauna with special characteristics, as the groups and growth rates of these biocommunities often reach high abundances (Dudley, 1997). Temporary ponds exist in various parts of the world, including Northern Europe (e.g.

\footnotetext{
*Corresponding author: elias@hcmr.gr
}

Williams, 1997; Angélibert et al., 2004; Nicolet et al., 2004), North America (e.g. Belk, 1998; Graham, 2002), Australia (e.g. Warwick and Brock, 2003), South Africa (e.g. Rhazi et al., 2001), while numerous temporary ponds also occur along the Mediterranean region (e.g. Grillas et al., 2004 and references therein).

Mediterranean Temporary Ponds (MTPs) are small, shallow water bodies that sustain water for a sufficiently long period of time (European Commission DG Environment, 2003, mainly during the winter and spring, thus allowing the development of (semi) aquatic vegetation and animal communities (Ramsar Convention, 2002). MTP's are characterized by their variable size, their hydrological functioning and the ephemeral nature of their wet phase (hydroperiod), their total dependence on the local meteorological and hydrological conditions and their unique vegetation and invertebrate communities (e.g. Wellborn et al., 1996; Spencer et al., 1999; Jakob et al., 2003; Grillas et al., 2004; Rhazi et al., 2004). Given the sensitivity of the eastern Mediterranean region to regional and hemispheric climate 


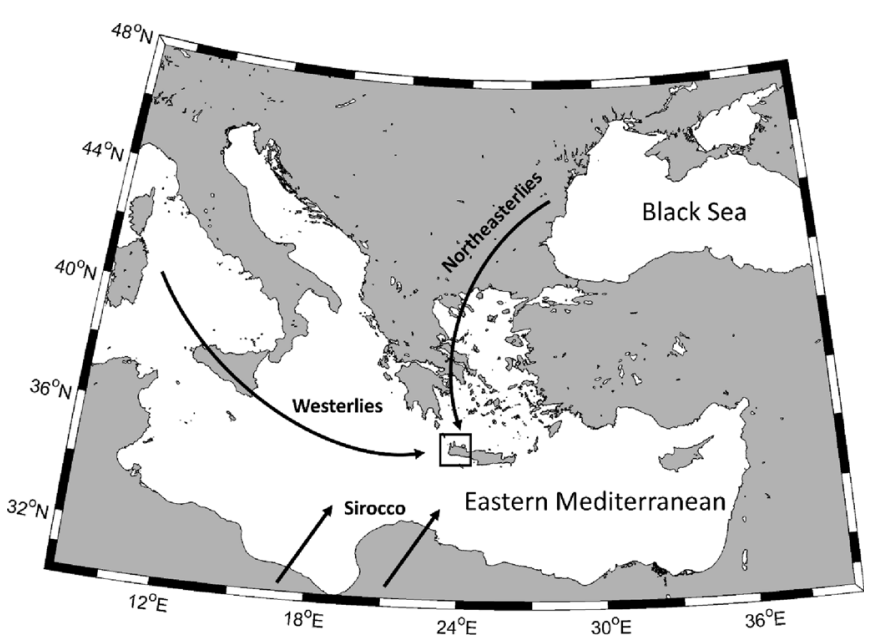

Fig. 1. General setting of the study area in relation to the main storm tracks and aeolian transport paths that influence the climate and environmental evolution of the island of Crete.

changes (e.g. Rohling et al., 2002; Marino et al., 2009; Durrieu et al., 2011; Kouli et al., 2012; Lionello, 2012; Gogou et al., 2016; Styllas et al., 2016; Athanasiou et al., 2017; Styllas and Ghilardi, 2017; and references therein), where arctic, temperate and monsoonal climate regimes meet (Lionello, 2012, Fig. 1), the study of MTP's can significantly contribute to our better understanding of climate-driven environmental processes, which consequently characterize their sedimentary, geochemical and biological regimes.

At present, there are 34 known MTPs in Greece, the majority $(68 \%)$ of which are located on islands (Dimitriou et al., 2006; Zacharias et al., 2007). The island of Crete being the largest island of Greece, hosts consequently the highest number of MTPs. There is strong consensus that MTPs are particularly vulnerable to climate changes (e.g. Lake et al., 2000; Poff et al., 2002), as recently, MTP's are characterized by increasing rates of extinction and loss of biodiversity resulting from anthropogenic habitat destruction and conversion, physiological stress, and interactions with invading and alien species (e.g. Vitousek, 1994; Hughes, 2000). The Omalos MTP in Western Crete (Fig. 1b and c) is located in an upland area, very important to biodiversity, as it hosts many rare species (Dimitriou et al., 2009) and is the focus of this study.

In this paper, we examine the potential of Omalos MTP sedimentary sequence in reconstructing the late Quaternary environmental changes that are representative of the conditions that occurred in the Eastern Mediterranean region, since the Lateglacial. Our analyses are based on the bulk major and trace elemental compositions, loss-on ignition, geochemical ratios, faunal (macroinvertebrate) and biotic traces (plant roots and stems), organic geochemistry and isotopic ratios, of sediment samples extracted from a littoral sediment core. The use of multivariate statistics and specific geochemical proxies, is employed in order to reconstruct the sediment sources over time, whereas faunal, biotic and isotopic ratios provide insight on the environmental changes of Omalos MTP. This study is among the first ones to assess the effects of regional environmental changes on the sedimentary regime of a MTP over such a long time scale.

\section{Regional setting}

\subsection{Site location, local geology and surface sediment properties}

The Omalos MTP $\left(35^{\circ} 19^{\prime} 35^{\prime \prime} \mathrm{N}, 23^{\circ} 53^{\prime} 15^{\prime \prime} \mathrm{E}\right)$ is located in Omalos polje, a karstic depression on the SW margin of the Samaria - Omalos plateau in Western Crete's Lefka Ori massif. The karstic depression has a circular shape with an area of $6000 \mathrm{~m}^{2}$, whereas Omalos MTP has a water surface area of $1600 \mathrm{~m}^{2}$, a water depth of $1.6 \mathrm{~m}$ and a hydroperiod of approximately 320 days per year (Stamati et al., 2008). The geology of the broader Omalos plateau is representative of the stacking pattern of nappes found in Western Crete, formed during the pre-alpine orogeny. The stratigraphy of Omalos plateau region is structured by three separate units, which from bottom to top are: (1) the Plattenkalk unit composed of Permian to Oligocene metacarbonate rocks, (2) the Trypali nappe, which lies tectonically over the Plattenkalk unit and consists of carbonate, recrystallized conglomerates, and brecciated limestones and dolomites of Triassic to Lower Jurassic age (Fytrolakis, 1980) and (3) the Phyllite-Quartzite unit, dated from Late Carboniferous to Late Triassic, which comprises a package of sedimentary rocks composed of quartz-rich siliciclastic elements, with minor limestone, gypsum and volcanic rocks (Richter et al., 1983). The rock formations around Omalos plateau are mainly part of the Trypali unit and less of the Plattenkalk group (Ten Veen and Meijer, 1999). The Plattenkalk formation together with the Phyllite and Quartzite formations make up for $75 \%$ of Omalos MTP catchment, which spans an area of $16000 \mathrm{~m}^{2}$ (Ghosn et al., 2010). Overlain to these rock formations are Neogene sediments composed from eroded material from the basal geological formations and include limestones, phyllites, quartzites and dolomites. Omalos MTP is located within the vicinity of the Neogene deposits (Fig. 1c), which are impermeable and retain water, thus the water coverage during wet and humid periods that postdate the Lateglacial ( $\sim 17 \mathrm{ka} \mathrm{BP})$, likely resulted in the formation of a temporary pond. Omalos MTP substrate is mainly composed of alluvial deposits, marls and silica enriched sediments.

The upper sediment layer $(0-50 \mathrm{~cm})$ of Omalos MTP littoral zone is acidic $(\mathrm{pH}=5.83)$, but below the depth of $50 \mathrm{~cm}$, the sedimentary sequence is basic. The organic matter is high $(6.45 \%)$ in the surface sediment layer; its average dry bulk density and porosity amount to $93.2 \%$ and $41 \%$, respectively (Stamati et al., 2008). Grain-size analyses of the non-gravel $(<2 \mathrm{~mm})$ fraction of the pond's surface sediments, are characterized as non-uniform (uniformity coefficient= 8.8 ) silty loam (sand $=32 \%$, silt $=64 \%$, clay $=4 \%$ ) for the outer part of the pond and as uniform (uniformity coefficient $=89$ ) sandy loam ( sand $=51 \%$, silt $=46 \%$, clay $=$ $3 \%$ ), along the littoral zone close to the core location. Silica $\left(\mathrm{SiO}_{2}\right)$ is the most abundant major element of the surficial sediments $(86.41 \%)$, while quartz is the most abundant mineral phase, with its content ranging between 4 and $100 \%$ (Stamati et al., 2008). Quartz deposition in the surface sediments, originates from the erosion of the phyllitequartzite formation and of the neogene deposits that dominate Omalos MTP catchment (Fig. 1c). 


\subsection{Climate and hydrology}

The island of Crete is positioned in the southern Aegean $\mathrm{Sea} /$ Eastern Mediterranean, an area that during the Lateglacial and the Holocene has comprised the crossroads of three major large-scale atmospheric circulation trajectories. In general, the wet season (October-April) climate of the southern Aegean Sea, when most storms occur, is mainly influenced by three major patterns illustrated in Figure 1a: (i) a west-east zonal circulation associated with North Atlantic-derived westerlies that move across the Mediterranean Basin, causing local cyclogenesis, and which in the study area are characterized by increased storminess, high amounts of precipitation and mild temperatures (Bartzokas et al., 2003), (ii) basin wide low winter temperatures and lack of precipitation over most of the North Aegean, but considerable snow and rain over the island of Crete, which are associated with enhanced frequency of northern and/or northeast continental, dry and cold airflow over Greece mostly driven by the Siberian High (Xoplaki et al., 2000), and (iii) hot African air drawn from the North African region, characterized by south to southeasterly (Sirocco) winds, associated with aeolian dust transport, that causes rainfall or dryness depending on the path of the air masses and their interaction with the Mediterranean Sea (e.g. Alpert et al., 2006). The interplay of these patterns largely controls the hydroperiod and sedimentation of Omalos MTP, with wet periods resulting to an extensive hydroperiod and detrital transport from the catchment, while polar outbreaks cause excessive snow in the Lefka Ori massif and thus increased groundwater recharge in the pond during the spring and early summer period. The wet and/or dry deposition of Saharan dust driven by the southerly and southwesterly Sirocco winds, is well-known for the island of Crete and occurs mainly during the spring months; its Holocene depositional rates range between 0.6 and $2 \mathrm{~cm} / 1000$ years (e.g. Nihlén et al., 1995), but can be considerably higher in concentration depressions, such as the one studied here.

The climate of western Crete is typical Mediterranean, characterized by moist winters and hot dry summers. Data derived from the Climate Research Unit (CRU) gridded $\left(0.5^{\circ} \times 0.5^{\circ}\right.$ grid cells) climatology (Harris et al., 2014) suggest that in the broader Omalos MTP region and between 1901 and 2014 , the mean annual temperature is $18^{\circ} \mathrm{C}\left(11.5^{\circ} \mathrm{C}\right.$ in January and $25.9^{\circ} \mathrm{C}$ in August) and the mean annual rainfall is $630 \mathrm{~mm}$. August is the driest month with zero precipitation, while December is the most humid month with $130 \mathrm{~mm}$, respectively. Overall, during the past century, the years with the lowest annual precipitation are characterized by the lowest temperatures (dry and cold years), as is indicated by the statistically significant positive correlation $(r=-0.59, p=0.03, a=0.05)$, between the 12 driest years of the record and the annual temperatures, while warm years with high annual temperatures occur with variable annual precipitation, but lack statistical significant correlations (Fig. 2).

The local climate in Omalos MTP, as indicated by in situ measurements from a meteorological station located very close to the pond, is influenced by its high elevation ( $1060 \mathrm{~m}$ a.s.1.), with higher mean annual precipitation $(1094 \mathrm{~mm})$ and lower mean annual temperatures $\left(9.3^{\circ} \mathrm{C}\right)$ (period of observations 1994-2012, Ghosn et al., 2010) when compared to the gridded dataset. Such discrepancies result from local effects and mainly from the orographic forcing, which is responsible for higher rainfall amounts and cooler temperatures at the location of the pond. The hydrology of Omalos MTP is simple, with the wet season (October-March) precipitation and the dry season (April-September) temperature and evaporation being the main drivers of its hydrological and, hence, sedimentological and biogeochemical processes.

The hydroperiod of Omalos MTP is rather steady and monthly measurements of lake's surface and ground water levels, indicate no significant interaction between them during the wet season, when ground water level is $16 \mathrm{~m}$ under the sediment water interface. However, during the late spring months the ground water level rises to $5 \mathrm{~m}$ below the sediment water interface (Stamati et al., 2008), as a result of the snowmelt season in the surrounding Lefka Ori Massif and subsequent aquifer recharge, but still the groundwater recharge of Omalos MTP is restricted. The ability of sediment for mineralization is influenced by the sediment moisture and exhibits a significant capacity, even at moisture levels of $40 \%$. Despite the high porosity the high amounts of fine (silt and clay) particles of Omalos MTP sediment, reduce the permeability so that the pond can retain water even after small rainfall events. The capacity of Omalos MTP sediment to leach out nitrogen and phosphorous is larger than the present dissolved concentrations of these elements in the pond's water, indicating the ability of the sediment to enhance the chemical composition of pond water. Batch leaching experiments under $20^{\circ} \mathrm{C}$ and for $\mathrm{pH}$ values of 5, 6 and 7 (Stamati et al., 2008), suggest that the leaching concentrations of the sediment was 11 times higher for ammonia $\left(\mathrm{NH}_{4}-\mathrm{N}\right)$ and 5 times for nitrite than the respective dissolved nutrient concentration in the pond $\left(\mathrm{NO}_{2}-\mathrm{N}\right)$ and at the same levels for nitrate $\left(\mathrm{NO}_{3}-\mathrm{N}\right)$. The total dissolved inorganic nitrogen leaching out of the sediment is increasing with $\mathrm{pH}$. The sediment of Omalos MTP showed higher mineralization capacity for nitrogen in comparison with phosphorous. Finally, the sediment has also a large capacity to adsorb phosphorous, however, the observed low levels of phosphorous in the aqueous phase makes the process inactive (Stamati et al., 2008).

\section{Materials and methods}

\subsection{Core retrieval and subsampling}

A $176 \mathrm{~cm}$-long core was retrieved from Omalos MTP littoral zone, $200 \mathrm{~m}$ away from the pond. The core location is within the vicinity of the phyllite-quartzite rock formations. The core was extracted in a relatively undisturbed way with a removable mechanical drill. Coring equipment consisted by a special mechanical head and a single plastic sampler $1.8 \mathrm{~m}$ long and $8 \mathrm{~cm}$ in diameter that was later split in four $45 \mathrm{~cm}-$ long segments. The core did not reach the substrate of Omalos MTP. Upon retrieval, tubes were covered with a plastic membrane to keep their moisture levels and were refrigerated at $2-5{ }^{\circ} \mathrm{C}$. The core material was subjected to X-ray fluorescence (XRF) together with carbon and nitrogen elemental and isotopic analyses. Soil subsampling for XRF analysis was realized where lithological changes were observed at the following core intervals: $9-10 \mathrm{~cm}, 31-$ $32 \mathrm{~cm}, 51-52 \mathrm{~cm}, 71-72 \mathrm{~cm}, 81-82 \mathrm{~cm}, 101-102 \mathrm{~cm}, 121-$ $122 \mathrm{~cm}, 141-141 \mathrm{~cm}$ and $171-172 \mathrm{~cm}$, whereas core subsampling for Total Organic Carbon (TOC), Total Nitrogen (TN) 

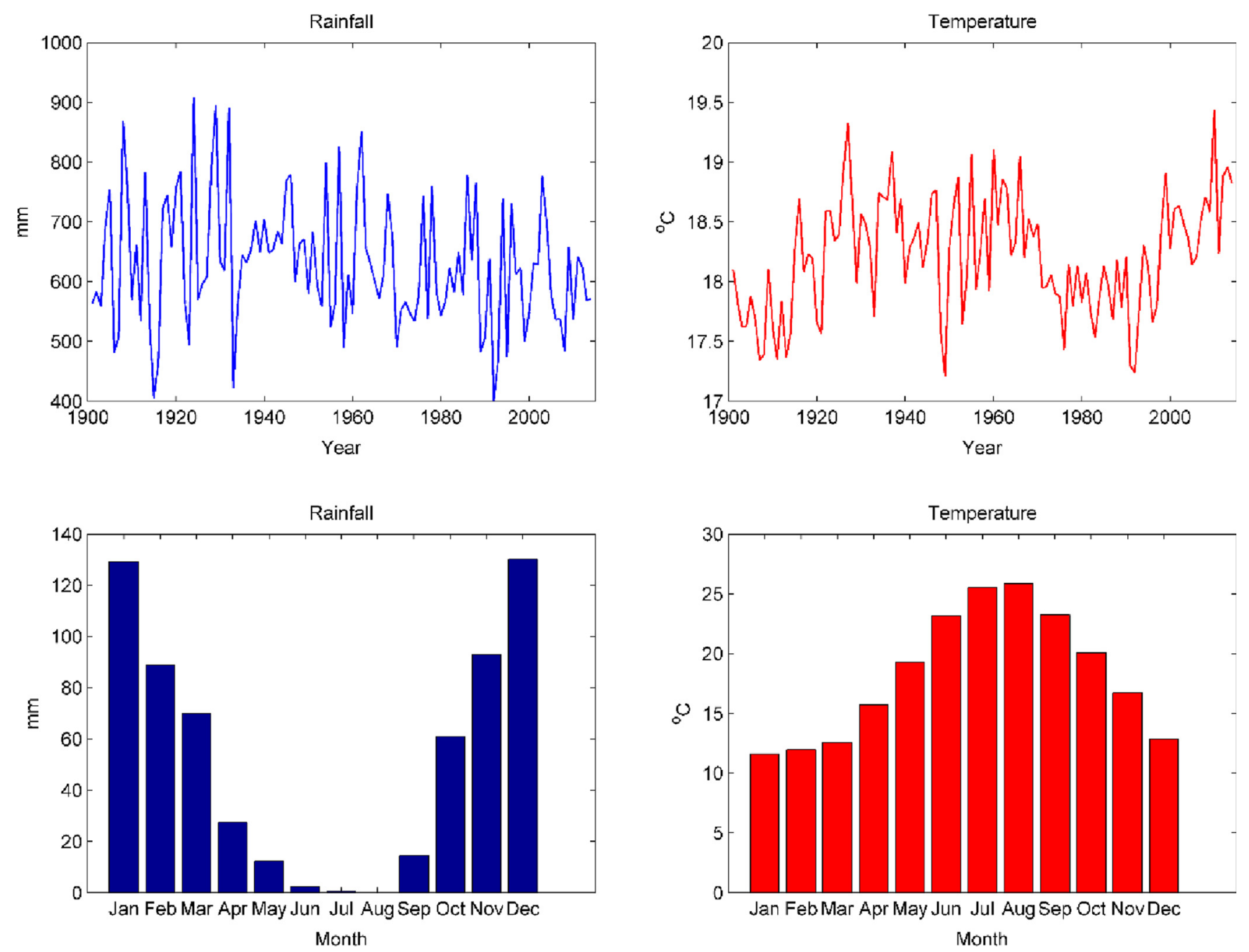

Fig. 2. Interannual variations of mean annual rainfall $(\mathrm{mm})$ and temperature $\left({ }^{\circ} \mathrm{C}\right)$ (upper diagrams) and their respective monthly means $($ lower diagrams) in Western Crete between 1901 and 1914, as derived from the CRU TS3.23 Version, grid cell centered at $35.25^{\circ} \mathrm{N}, 23.75^{\circ} \mathrm{E}(\mathrm{Harris}$ et al., 2014).

Table 1. Radiocarbon dates from Omalos MTP littoral core.

\begin{tabular}{llllll}
\hline Sample id & Dating Method & Material & Lab no. & Age $\left({ }^{14} \mathrm{C} \mathrm{BP}\right)$ & \pm \\
\hline OM 1 & AMS & Organic sediment & Poz-20746 & 4200 & 35 \\
OM 2 & AMS & Organic sediment & Poz-20747 & 13660 & $4692 \pm 73$ \\
\hline
\end{tabular}

and stable isotopic ratios $\left(\delta^{15} \mathrm{~N}\right.$ and $\left.\delta^{13} \mathrm{C}\right)$, was performed at: $1-2 \mathrm{~cm}, 6-7 \mathrm{~cm}, 9-10 \mathrm{~cm}, 34-35 \mathrm{~cm}, 47-48 \mathrm{~cm}, 54-55 \mathrm{~cm}$, 64-65 cm, 78-79 cm, 87-88 cm, 93-94 cm, 104-105 cm, 112$113 \mathrm{~cm}, 127-128 \mathrm{~cm}, 135-136 \mathrm{~cm}, 145-146 \mathrm{~cm}, 155-156 \mathrm{~cm}$ and $166-167 \mathrm{~cm}$. The samples were taken from the middle of each core slice in order to avoid potential contamination from the drilling process.

\subsection{Radiocarbon dating}

Two radiocarbon dates (Poznan Radiocarbon Laboratory, Poland) were obtained from organic rich sediment rich in terrestrial remains (stems and plant remains) retrieved at core depths of $80-95 \mathrm{~cm}$ and $170-176 \mathrm{~cm}$, respectively (Tab. 1). The chronology at the base at the core $(170-176 \mathrm{~cm}$ depth), is indicative of the Late glacial to mid-Holocene sedimentation conditions, whereas the second dating was realized in organic rich bulk sediment at $80-95 \mathrm{~cm}$, a depth that marks a distinct lithological change, expressed by a marked color change from light grey to dark grey. Radiocarbon dates were calibrated with the Calib 6.1.1 Software (Stuiver et al., 2005) by utilizing the IntCal04 calibration curves for terrestrial samples (Reimer et al., 2004). These specific sampling depths were selected due to the distinctive changes in the organic content and cover the period from the Lateglacial to present. 


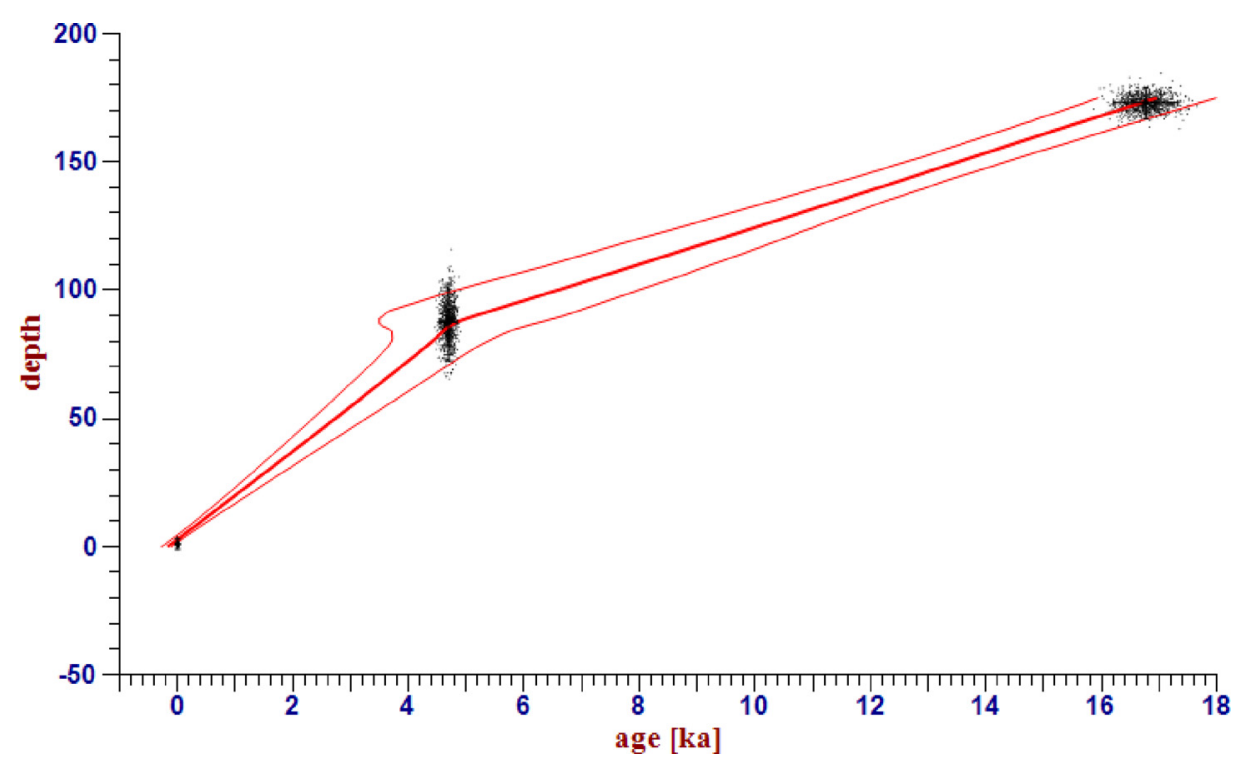

Fig. 3. Age-depth model for Omalos MTP as resulted from the two radiocarbon dates and point $(0,0)$ through the application of MOD-AGE algorithm.

A crude age-depth model was constructed with the help of MOD-AGE algorithm (Fig. 3), which uses minimum assumptions about the age probability distributions. A normal distribution is assumed for most basic data obtained from measurements and is used for the model construction (Hercman and Pawlack, 2012).

\subsection{Bulk geochemical compositions}

XRF analyses were performed at HCMR through a Philips PW-2400 X-ray wavelength spectrometer, where major elements were determined in fused beads and minor elements in pressed powders. Major compounds and trace elements were identified by XRF spectrometry as follows: Major elements (weight \%): $\mathrm{Al}_{2} \mathrm{O}_{3}, \mathrm{SiO}_{2}, \mathrm{P}_{2} \mathrm{O}_{5}, \mathrm{~K}_{2} \mathrm{O}, \mathrm{CaO}, \mathrm{TiO}_{2}, \mathrm{Fe}_{2} \mathrm{O}_{3}, \mathrm{Na}_{2} \mathrm{O}$, $\mathrm{MgO}, \mathrm{SO}_{4}^{-2}, \mathrm{MnO}, \mathrm{Cr}_{2} \mathrm{O}_{3}$; Trace elements (ppm): $\mathrm{Sc}, \mathrm{V}, \mathrm{Cr}, \mathrm{Mn}$, $\mathrm{Co}, \mathrm{Ni}, \mathrm{Cu}, \mathrm{Zn}, \mathrm{Ga}, \mathrm{As}, \mathrm{Br}, \mathrm{Rb}, \mathrm{Sr}, \mathrm{Zr}, \mathrm{Nb}, \mathrm{Mo}, \mathrm{Sn}, \mathrm{I}, \mathrm{Ba}, \mathrm{La}, \mathrm{Ce}$, $\mathrm{Nd}, \mathrm{W}, \mathrm{Pb}, \mathrm{Th}$ and $\mathrm{Y}$. The relationships between major elements were explored using Principal Component Analysis (PCA), which was performed on the standardized values matrix of the weight percentages, using MATLAB ${ }^{\odot}$ software.

\subsection{Loss-on-ignition, organic matter}

The weight loss-on-ignition, was determined by continuously retrieving volumetric samples of $1 \mathrm{~cm}^{3}$ and drying them overnight at $105^{\circ} \mathrm{C}$, before the dry weight was measured. The weight loss-on-ignition (LOI, \%) was calculated as percent of the sediment dry weight and was determined through subjection of each sediment sample to increasing temperatures to be finally ignited at $550^{\circ} \mathrm{C}$ for $1 \mathrm{~h}$, so that the total organic matter (OM, \%) of Omalos MTP sedimentary sequence was calculated.

\subsection{Organic carbon, total nitrogen, $\delta^{13} \mathrm{C}_{\text {org }}$ and $\delta^{15} \mathrm{~N}_{\text {tot }}$ analyses}

Organic carbon, total nitrogen and their stable isotopes $\left(\delta^{13} \mathrm{C}_{\text {org }}\right.$ and $\left.\delta^{15} \mathrm{~N}_{\text {tot }}\right)$ were determined on carbonate-free samples (washed three times with $1 \mathrm{M} \mathrm{HCl}$ ) using a Thermo 1500 elemental analyzer coupled to a continuous-flow gas isotope ratio mass spectrometry instrument (Finnigan MAT 252). The observed changes in the aforementioned parameters along the core were analyzed in combination with the results from a recent pollen analysis study in the same core (Ghosn et al., 2010). The output of this process was the interpretation of the major environmental changes in Omalos MTP during the last 17000 years.

\subsection{Biotic habitats}

Aquatic macroinvertebrates were collected from the surface of the Omalos MTP bottom with a $500 \mu \mathrm{m}$ mesh attached on square framed hand net $(0.25 \times 0.25 \mathrm{~m})$, based on a long arm. The organisms were captured by the sampler caused disturbance of the bottom following the basic principles of the AQEM method (AQEM Consortium, 2002) including detailed recording of various environmental and geomorphologic parameters on hydro geomorphology, anthropogenic pressures, land uses etc. The relative importance of the various multi-habitats within the sampling area was taken into account in order to achieve better evaluation of biodiversity. Two main habitats were distinguished. Habitat A, at the littoral zone of the pond, was covered from filamentous algae and bluegrass on a substrate of fine sand and silt. Habitat B, located at the center of the pond, was mostly covered by silt and low concentrations of fine sand. From each of the two main habitats, 15 replicates were obtained. After sampling, the material was transferred to a clean container with $95 \%$ ethanol as a preservative and stored for taxonomic classification in the laboratory, according to Tachet et al. (2010) with an Olympus SZX10 stereomicroscope. From the Omalos MTP core, soil subsamples of $9.62 \mathrm{~cm}^{3}$ volume were taken every $5 \mathrm{~cm}$. Each sample was placed in a special container with an attached $250 \mu \mathrm{m}$ planktonic net and rinsed in tap water. The recovered particles of biotic material were placed in vials with $95 \%$ ethanol in 
Table 2. Major element geochemistry (weight \%) and loss-on-ignition differences between the Plattenkalk formation (28 samples after Massi et al., 2002), Omalos MTP surface (Stamati et al., 2008) and Omalos MTP core top $(10 \mathrm{~cm})$ sediments retrieved from the littoral zone (this study). Bold lettering denotes the most dominant phase.

\begin{tabular}{llllllllllll}
\hline Sediment type & $\mathrm{LOI}$ & $\mathrm{Al}_{2} \mathrm{O}_{3}$ & $\mathrm{SiO}_{2}$ & $\mathrm{P}_{2} \mathrm{O}_{5}$ & $\mathrm{~K}_{2} \mathrm{O}$ & $\mathrm{CaO}$ & $\mathrm{TiO}_{2}$ & $\mathrm{Fe}_{2} \mathrm{O}_{3}$ & $\mathrm{Na}_{2} \mathrm{O}$ & $\mathrm{MnO}^{2}$ & $\mathrm{MgO} \mathrm{O}$ \\
\hline Plattenkalk & 43.4 & 0.23 & 0.77 & 0.03 & 0.03 & 55.17 & 0.02 & 0.08 & 0.02 & 0.11 & 0.05 \\
Omalos MTP surface & 6.45 & 6.41 & 86.4 & 1.34 & 1.15 & 0.25 & 0.31 & 2.86 & 0.00 & - & 0.82 \\
Omalos MTP core top sample (littoral zone) & 5.76 & 6.74 & 82.1 & 0.09 & 0.96 & 0.08 & 0.34 & 2.86 & 0.04 & 0.38 & 0.6 \\
\hline
\end{tabular}

order to obtain the closest possible taxonomic identification, using the above-mentioned laboratory equipment.

\section{Results}

\subsection{Surface sediment sources}

The most abundant geochemical component of Omalos MTP surface sediments is $\mathrm{SiO}_{2}$, which accounts for $86 \%$ of the major element compositional suite of the pond's surface sediments (Tab. 2). $\mathrm{SiO}_{2}$, together with $\mathrm{Al}_{2} \mathrm{O}_{3}$ and $\mathrm{K}_{2} \mathrm{O}$ are the main elements associated with the alumino-silicate fraction and are present in primary silicates as, for example, feldspars and in secondary minerals, as clays. The high $\mathrm{SiO}_{2}$ and $\mathrm{Al}_{2} \mathrm{O}_{3}$ concentrations of Omalos MTP core suggest that the littoral zone and the pond sediment geochemistry is mostly composed of weathered material from the Phyllite-Quartzite formation and the quartz-rich Neogene deposits. Higher $\mathrm{SiO}_{2}$ values $(86.4 \%)$ are observed in the pond's surface sediments (Section 2.1 ) and this enrichment likely reflects other $\mathrm{SiO}_{2}$ contributions, such as aeolian and biogenic inputs. The composition of Sahara dust in Lefka Ori and Omalos MTP surroundings has been found to be rich in quartz and kaolinite (Nihlén et al., 1995). However, the variable quartz content in the pond's surface sediments (Section 2.1) ranges between $4 \%$ and $100 \%$, and implies that in addition to the aeolian input, high $\mathrm{SiO}_{2}$ concentrations in the surface and core sediments can be also of biogenic origin, especially during period of high primary productivity. We therefore consider that $\mathrm{SiO}_{2}$ concentrations of Omalos MTP core represent both the allogenic (catchment derived and aeolian) and authigenic (biogenic) fractions, so that the downcore $\mathrm{SiO}_{2}$ variability reflects changes in both sediment transport from the catchment and/or in Omalos MTP surface water productivity. In contrast to the allogenic alumino-silicate fractions derived from the phyllite-quartzite and the neogene sediments, the Plattenkalk formation, also present in the catchment area appears to have minor contributions to the detrital fraction, as evidenced by the comparison of the weight $\%$ concentrations of major geochemical compounds between the Plattenkalk formation and Omalos MTP surface and core top sediments (Tab. 2).

\subsection{Macroinvertebrates and biotic particles}

A total number of 15627 macroinvertebrate individuals were collected and identified from littoral Habitat A, (sand silt covered by filamentous algae/bluegrass vegetation) at mean water depth of $10 \mathrm{~cm}$ (Tab. 3), close to Omalos MTP core location. Calanoida was the most abundant group with a huge number of individuals. Hemiptera, Coleoptera, Ostracoda and
Table 3. Invertebrate fauna from the two habitat types of Omalos MTP.

\begin{tabular}{|c|c|c|}
\hline Macroinvertebrates & $\begin{array}{l}\text { Habitat A } \\
\text { (Omalos MTP } \\
\text { littoral zone) }\end{array}$ & $\begin{array}{l}\text { Habitat B } \\
\text { (Omalos } \\
\text { MTP center) }\end{array}$ \\
\hline Ostracoda & 3 & - \\
\hline Calanoida (Copepoda) & 15600 & 18 \\
\hline Laccophilus minutus (Coleoptera) & 4 & - \\
\hline Ilybius sp. (Coleoptera) & 4 & - \\
\hline Rhantus sp. (Coleoptera) & 3 & - \\
\hline Corixa sp. (Hemiptera) & 3 & 2 \\
\hline Plea sp. (Hemiptera) & 6 & 7 \\
\hline Notonecta sp. (Hemiptera) & - & 5 \\
\hline Chironomus riparius (Diptera) & - & 3 \\
\hline Chironomus sp.1 (Diptera) & - & 27 \\
\hline Chironomus sp.2 (Diptera) & - & 42 \\
\hline Chironomus sp.3 (Diptera) & - & 81 \\
\hline Artemia sp. (Branchiopoda) & - & 6 \\
\hline Haplotaxis sp. (Oligocheata) & 2 & 18 \\
\hline Lumbriculus sp. (Oligocheata) & 2 & 26 \\
\hline
\end{tabular}

Oligocheata followed, with few individuals. In Habitat B, with mean water depth of $50 \mathrm{~cm}$, a total number of 235 individuals were collected. Only 18 Calanoida individuals were measured while no Coleoptera species were found. The group of Hemiptera was present, as well as Oligocheata but the latter with several more individuals, compared to the Habitat A. Among other macroinvertebrate taxa individuals of Artemia sp., Oligocheata, and especially four different Diptera species including the Chironomus riparius larvae, a typical bioindicator for anoxic conditions were also collected. According to Weber et al. (1985), this is due to the $\mathrm{O}_{2}$ affinities, Bohr and temperature effects of its isohemoglobins in relation to the lifecycle and the common micro environmental natural status of these organisms with regard to the molecular mechanisms underlying the Hb-oxygenation reactions. Such hypoxic incidents are common and occur usually in Omalos MTP, caused by the effluents deriving from livestock activities in the area.

Regarding the collected biotic material from the sampled core, the dominant herbal material consisted mainly from very small parts from fine roots and plant's stems. Each part from those materials had a mean length of $2 \mathrm{~mm}$. The number of the found Particulate Organic Matter (POM) at the relevant depth is represented in Figure 4. Overall, the parts of fine roots were more abundant than those of plant's stems, especially at the lower and upper parts of the core $(155,35$ and $5 \mathrm{~cm}$ of core 


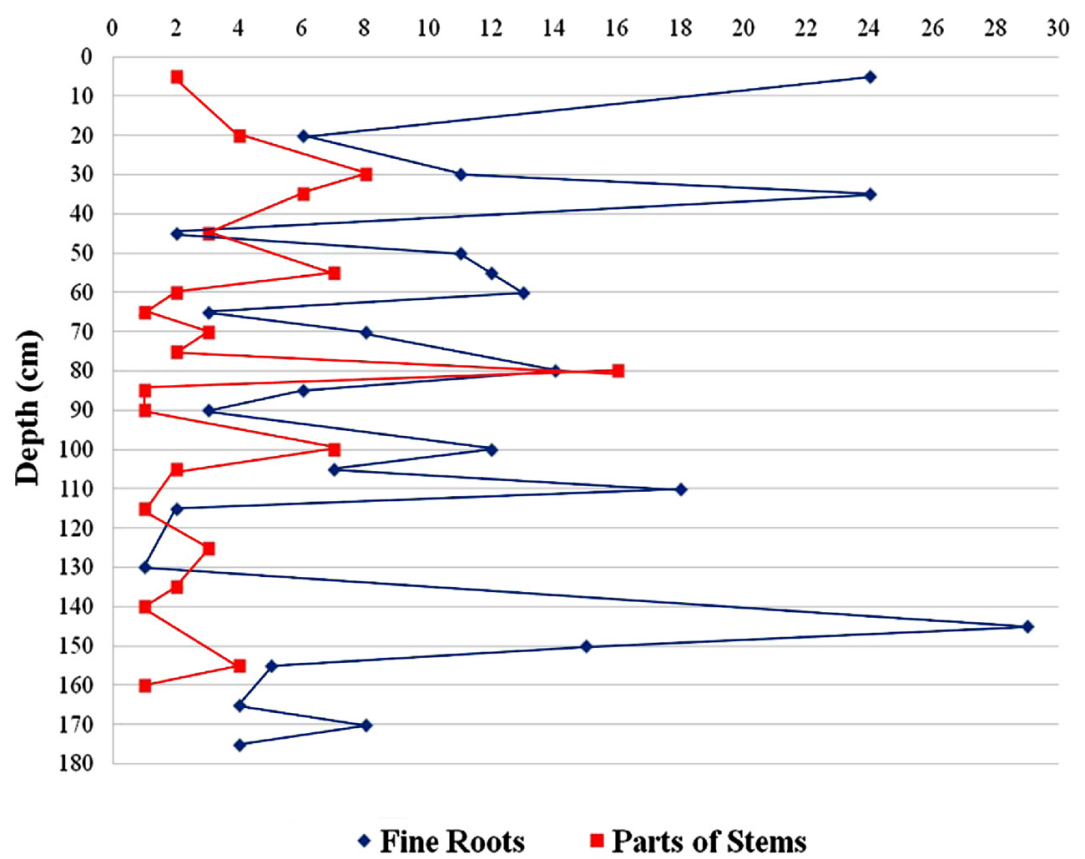

Fig. 4. Number of plant particles (fine roots and plant's stems) along Omalos MTP core.

depth), suggesting the establishment and/or expansion of littoral vegetation during the Lateglacial and the late Holocene, whereas plant's stems show the highest values in the middle of the core $(80 \mathrm{~cm})$, a period that according to our general agemodel, corresponds to the mid-Holocene.

Due to the fact that usually the body of macroinvertebrates is not fully covered by chitin, when decomposed it is very difficult to identify them with optical methods employed here. Despite this situation, an individual of Limnephilus sp. (Trichoptera) was found in a subsample near the core top. This identification was based on the remaining parts of this Trichoptera larva individual: coxa, trochanter, femur, tibia, tarsus and tarsal claw, parts of mesopleurites, protochantin, prosternite, ventral apotome, gena of parietal, anal proleg claw with accessory hook and the 9th abdominal dorsal sclerite (Wallace et al., 1990). Also, from the upper $5 \mathrm{~cm}$, parts from Chara sp. and Polytrichum sp. were collected. In the same subsample a part of mollusca was also found. Deeper than the latter subsample and at core depths of $85-100 \mathrm{~cm}(<4.7 \mathrm{ka} \mathrm{BP})$, two individuals of Ostracoda were found, suggesting a change in Omalos MTP paleohydrology and/or trophic status, during the mid-Holocene.

\subsection{General changes in core stratigraphy and geochemistry}

Two stratigraphic units (Unit I and Unit II), were identified on the basis of lithological changes, sediment texture and color. The basal unit (Unit II, 170-96 cm core depth), spans the time interval from the Lateglacial to mid-Holocene (16.7-4.7 ka) and consists of massive, clay and silt populations of gray color. The upper part of the core (Unit I, $80-0 \mathrm{~cm}$ core depth), is of Late Holocene age ( $4.7 \mathrm{ka}$ to present) and consists of gray to black organic rich silts with no signs of laminae, and increasing lenses of fine sand along upper part. Roots and stems are observed throughout the entire length of the core (Section 4.2,
Fig. 4). The simple stratigraphic model with the two radiocarbon ages, provides a general estimate for sedimentation rates that appear to be two times larger in Unit I. From the Lateglacial to mid-Holocene (16.7-4.7 ka BP) the average sedimentation rate in the core location is $\sim 8 \mathrm{~cm} / \mathrm{ka}$, while from $4.7 \mathrm{ka} \mathrm{BP}$ to present is $\sim 17.4 \mathrm{~cm} / \mathrm{ka}$. The low sedimentation rates of Unit II may be attributed to different reasons, such as climatic deteriorations and dry conditions with marginal hydrological activity for the transportation of weather material from the catchment that resulted in diminished sediment inputs to the temporary pond. The existence of the temporary pond during this long time interval, is attested by frequent appearance of aquatic Isoetes along various horizons of Unit II, but the overall minimal pollen concentrations ( $<5$ grains/ $\mathrm{cm}^{3}$ ) of Unit II, point to a "blank period" in the vegetation cover of Omalos MTP catchment (Ghosn et al., 2010).

The geochemical stratigraphy of Omalos MTP inorganic compounds and trace elements is summarized in Figures 5 and 6. $\mathrm{SiO}_{2}(76.6-83.3 \%), \mathrm{Al}_{2} \mathrm{O}_{3}(5.9-9.6 \%)$ and $\mathrm{Fe}_{2} \mathrm{O}_{3}(4.4$ $2.8 \%$ ), are the major compounds throughout the core. All samples are strongly depleted in $\mathrm{CaO}(0.1-0.06 \%)$ and $\mathrm{Na}_{2} \mathrm{O}$ $(0.07-0.03 \%)$. The sediments of Unit II show, lower $\mathrm{SiO}_{2}$ and higher $\mathrm{Al}_{2} \mathrm{O}_{3}, \mathrm{Fe}_{2} \mathrm{O}_{3}$, and $\mathrm{TiO}_{2}$ concentrations, which decrease sharply above the transition layer between Unit I and Unit II at $4.7 \mathrm{ka}$ BP (Fig. 3). LOI, which measures the organic matter (OM), does not exhibit considerable fluctuations (6.3-5.3\%) and follows the general pattern of $\mathrm{Al}_{2} \mathrm{O}_{3}, \mathrm{Fe}_{2} \mathrm{O}_{3}$ and $\mathrm{K}_{2} \mathrm{O}$, with decreasing values along Unit I.

Minor element geochemistry is dominated by the presence of $\mathrm{Mn}$ (1500-4150 ppm), which shows a 3-fold increase compared to the pond's surface samples $(\mathrm{Mn}=464.4$, Stamati et al., 2008) and fluctuates throughout the core with two peaks in Unit I (Fig. 6). The enrichment of $\mathrm{Mn}$ (and $\mathrm{MnO}$ ) follows the $\mathrm{Fe}_{2} \mathrm{O}_{3}$ trend in Unit II, that is probably caused by the coprecipitation of Fe and Mn oxides in the core location, but shows a different pattern in Unit I (Figs. 5 and 6). Peak values of Mn 

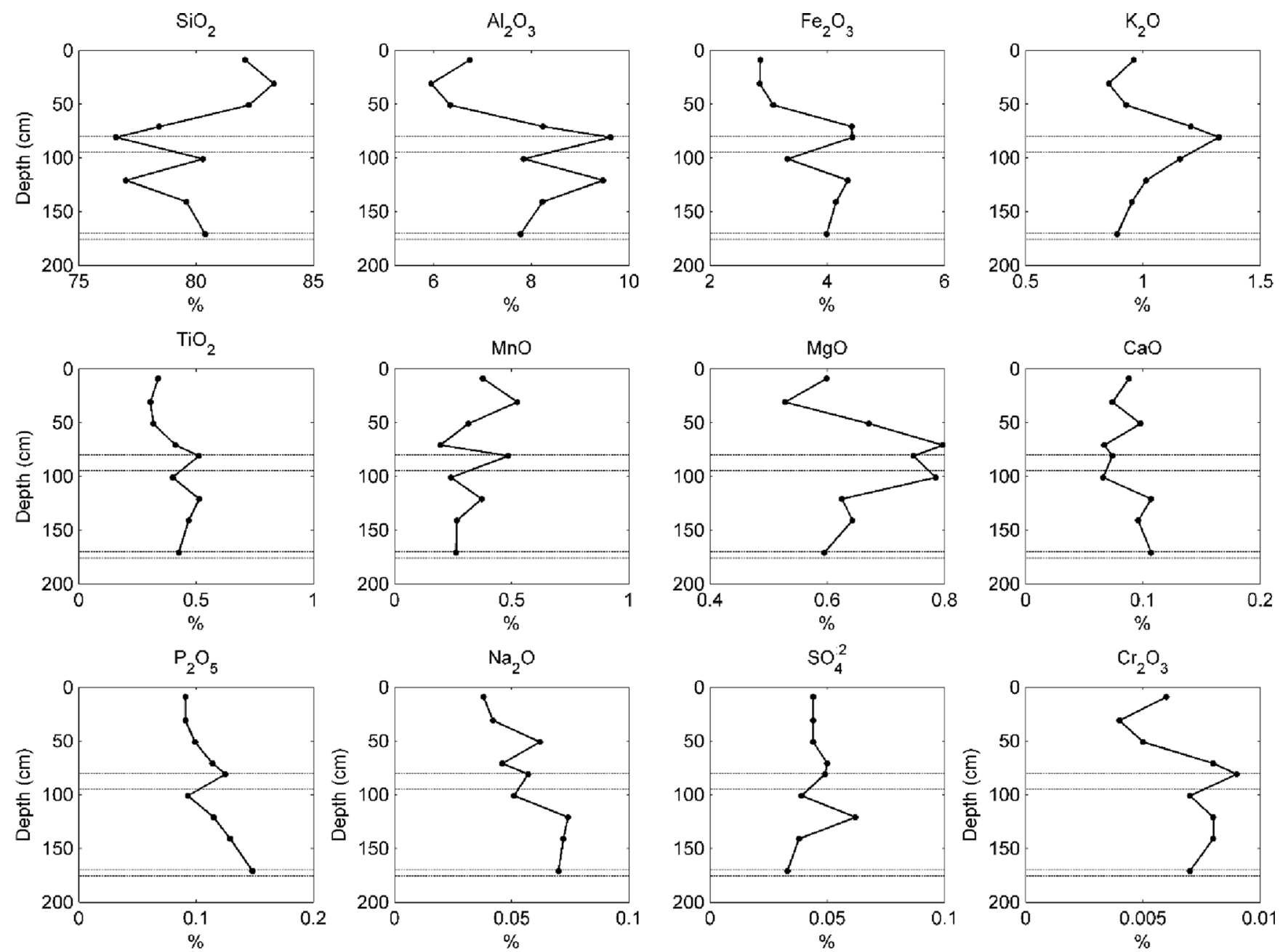

Fig. 5. Downcore variations of Omalos MTP major inorganic compounds. Dashed lines represent the dated layers at the bases of Unit II (16.7 ka $\mathrm{BP})$ and in the transition layer between Units II and I (4.7 ka BP).

and $\mathrm{MnO}$ at $32 \mathrm{~cm}$ of core depth, correspond to a peak fine plants roots values of the core sediment (Fig. 4) and may be related to the decay of aquatic vegetation and of the bluegrass and filamentous algae found in the littoral zone (Habitat A), with release of Mn during a period of intense water column thermal stratification and overall anoxic conditions. Iodine also shows high concentrations (426-473 ppm) compared to the other trace elements, displaying an increasing trend from the bottom to the top of Omalos MTP core (Fig. 6).

The most remarkable feature of the downcore distribution of Omalos MTP geochemical compounds and trace elements illustrated in Figures 5 and 6 , is expressed by the peaks of $\mathrm{Al}_{2} \mathrm{O}_{3}, \mathrm{Fe}_{2} \mathrm{O}_{3}, \mathrm{~K}_{2} \mathrm{O}, \mathrm{MgO}, \mathrm{Cr}_{2} \mathrm{O}_{3}, \mathrm{~V}, \mathrm{Zn}, \mathrm{Ga}$, in core depths between 96 and $80 \mathrm{~cm}$, a period that according to the radiocarbon calibrated age corresponds to the mid-Holocene (4.7 ka BP). The peak values of these inorganic compounds and trace elements, occur simultaneously with the lowest values of $\mathrm{SiO}_{2}$, suggesting a major disturbance of the Omalos MTP inorganic geochemistry. Von Eynatten et al. (2012) emphasize the importance of mechanical processes on sediment grain-size distribution and showed that concurrent increases in $\mathrm{Al}_{2} \mathrm{O}_{3}$ and decreases in $\mathrm{SiO}_{2}$ concentrations, occur with changes in sedimentation towards finer grain sizes.
Therefore, the mid-Holocene "geochemical event", expressed by the highest/lowest $\mathrm{Al}_{2} \mathrm{O}_{3} / \mathrm{SiO}_{2}$ concentrations in Omalos MTP littoral zone, was likely characterized by the limited sediment transport capacity of the coarser $\mathrm{SiO}_{2}$ particles, in favor of finer $\mathrm{Al}_{2} \mathrm{O}_{3}$ particles, which could be more easier transported from the catchment towards the pond during a period of reduced moisture and of dry conditions.

\subsection{PCA of OM, major compounds and trace elements}

To better understand the inter-relationships between the geochemical compounds and trace elements of Omalos MTP sediment core, a PCA was carried out. The dataset ( 9 samples $\times 37$ variables) included, the standardized values of LOI, and all major geochemical compounds and trace elements. The normalization (subtracted the mean, divided by the standard deviation) of the raw data, is appropriate due to the different units of the variables and ascribes equal weight to all variables. The results showed that the first two principal components (PC1, PC2) explained $73.4 \%$ of the total variance. The first PC axis (PC1) of the PCA, explains $56.6 \%$ of the total variance and is characterized by the very strong anticorrelation 

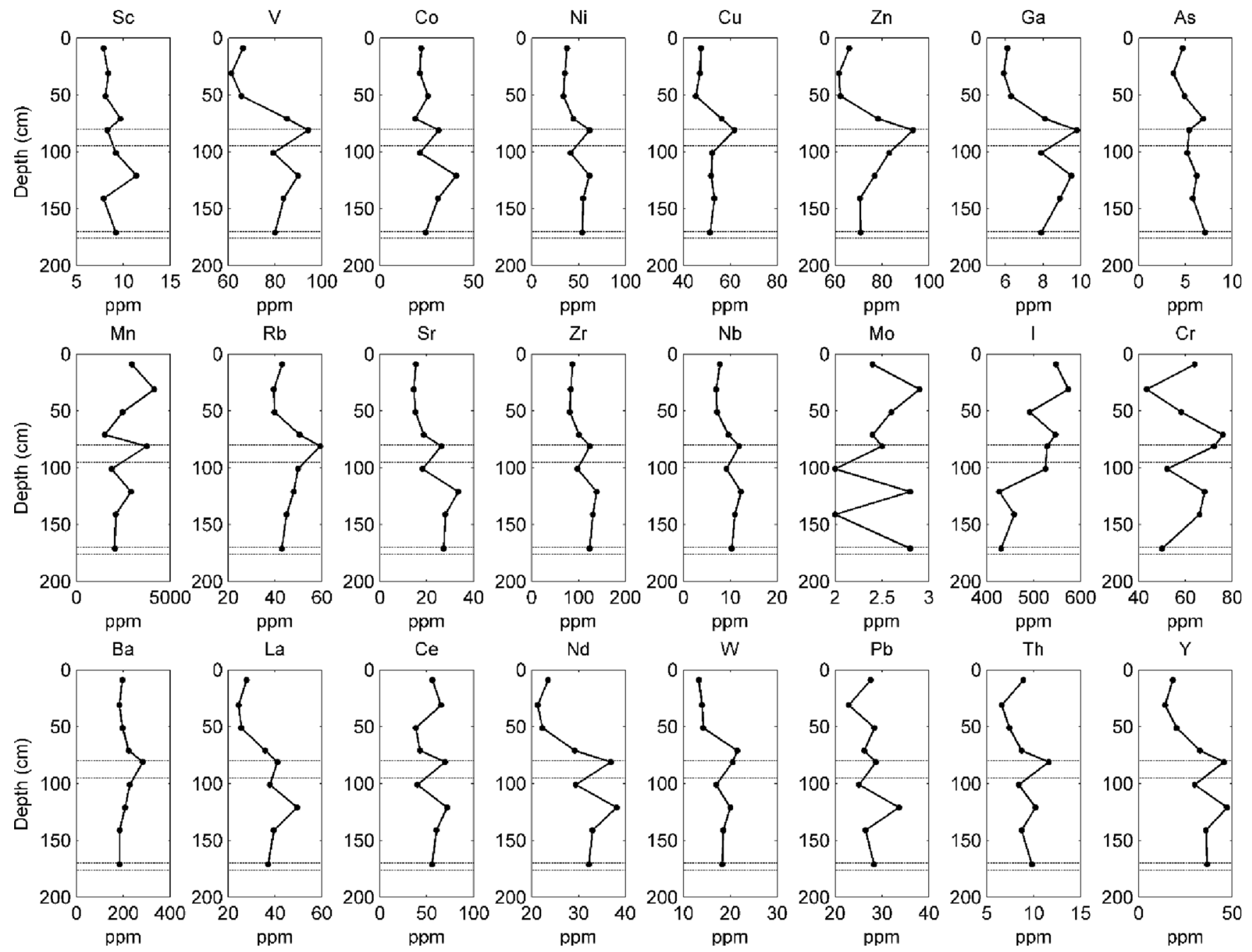

Fig. 6. Vertical concentration profiles of Omalos MTP core trace elements. Dashed lines represent the dated layers at the bases of Unit II (16.7 ka BP) and in the transition layer between Units II and I (4.7 ka BP).

with the $\mathrm{SiO}_{2}(r=-0.98)$ and also by the high PC loadings (correlations) with the other detrital geochemical compounds such as $\mathrm{Al}_{2} \mathrm{O}_{3}(0.99)>\mathrm{TiO}_{2}(0.98)>\mathrm{Cr}_{2} \mathrm{O}_{3}(0.94)>\mathrm{Fe}_{2} \mathrm{O}_{3}$ (0.93), suggesting a contrasting transport behavior and/or origin between $\mathrm{SiO}_{2}$ and these elements (Fig. 7). Additionally, to $\mathrm{SiO}_{2}$, on the negative side of $\mathrm{PCl}$ axis, are the redox sensitive manganese $(\mathrm{Mn})$ and its oxide $(\mathrm{MnO})$, as well as Mo and I. Trace elements with the highest $\mathrm{PC} 1$ loadings are $\mathrm{Y}$

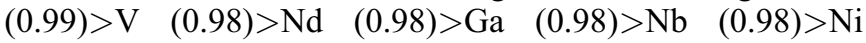
$(0.94)>\operatorname{Zr}(0.9)>\operatorname{Sr}(0.87)$. Aluminum is generally considered as allogenic, conservative and insoluble element under most sedimentary conditions (Engström and Wright, 1984) and here is interpreted to represent the clastic fine sediment input from allochthonous sediment sources, transported under overall dry conditions ( $\mathrm{PC} 1$ positive scores). On the contrary, the increased $\mathrm{SiO}_{2}$ sedimentation is linked to overall wet conditions, with enhanced transport of coarser sediment particles from the catchment and to high water levels of Omalos MTP that during extremely wet periods possibly inundated the core location. Dry conditions and transport of fine particles towards the pond (PC1 negative scores), would have resulted to reductive conditions of the sediment column.
The latter finds firm evidence in the negative correlation ( $r=-0.6, p=0.08, a=95 \%$ ) between $\mathrm{PC} 1$ scores and $\mathrm{MnO} /$ $\mathrm{Fe}_{2} \mathrm{O}_{3}$; a ratio representative of the oxic/anoxic (high/low values) conditions through changes in the sediments redox (Eh). Periods with high $\mathrm{MnO} / \mathrm{Fe}_{2} \mathrm{O}_{3}$ ratios correspond to increased effective moisture (Jiménez-Espejo et al., 2014), which for the case of Omalos MTP may have resulted to increasing water saturation and oxic conditions of the littoral sediments. Therefore, negative/positive $\mathrm{PC} 1$ scores are interpreted to correspond to oxic/anoxic conditions of the sediment sequence (high/low $\mathrm{MnO} / \mathrm{Fe}_{2} \mathrm{O}_{3}$ values) that are linked to overall wet/dry environmental conditions. The profile distribution of PC1 reveals positive scores for Unit II and negative scores in Unit I (Fig. 8), which implies that the wetter conditions and sediment transport of coarser $\mathrm{SiO}_{2}$-rich particles from the catchment to Omalos MTP occurred in parallel with water saturation and/or partial inundation of the core location from the mid-Holocene onwards.

PC2 explains another $16.7 \%$ of the total variance. Two clusters are formed along $\mathrm{PC} 2$ axis, which anti-correlate with each other (Fig. 8). The first cluster is dominated by $\mathrm{CaO}$ and $\mathrm{Na}_{2} \mathrm{O}$ and the second cluster is related to $\mathrm{K}_{2} \mathrm{O}, \mathrm{MgO}$ and LOI, as 


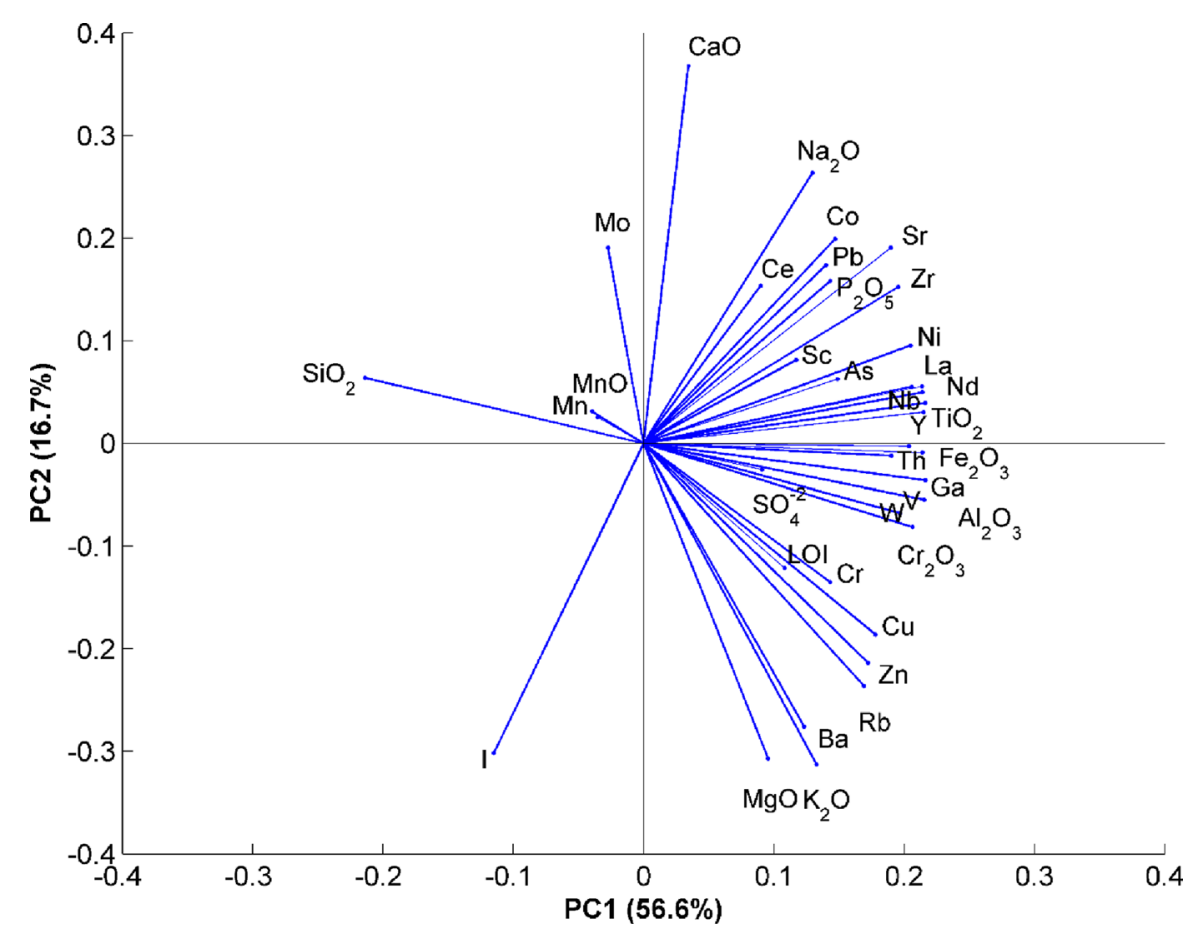

Fig. 7. Biplot based on principal components analysis performed on the weight \% concentrations of Omalos MTP major inorganic compounds, weight (\%) of loss-on-ignition (LOI) and trace element concentrations ( $m=37)$ for the $n=9$ sampled horizons along the core. The scores of each element are plotted along the first two principal components axes PC1 and PC2, which represent 56.6\% and $16.7 \%$ of the total variance, respectively.

suggested by their high positive and negative scores, respectively (Fig. 7). $\mathrm{CaO}, \mathrm{Na}_{2} \mathrm{O}, \mathrm{Co}$ and $\mathrm{Sr}$ show the highest positive loadings $(0.92,0.65,0.49,0.47)$ on the PC2 axis, while negative loadings are found for $\mathrm{K}_{2} \mathrm{O}(-0.79), \mathrm{MgO}(-0.77), \mathrm{Ba}$ $(-0.69)$ and $\mathrm{Rb}(-0.66)$. Thus, $\mathrm{PC} 2$ reflects the sedimentation gradient from carbonate $(\mathrm{Ca}$ and $\mathrm{Sr})$ to clay $\left(\mathrm{K}_{2} \mathrm{O}, \mathrm{MgO}\right.$ and $\mathrm{Rb}$ ) dominated sedimentation. The deposition of carbonate is expressed by the positive PC2 scores, while clay silicates are represented by negative PC2 scores (Fig. 7). The highest positive values of PC2 scores, occur in the transition layer between Unit II and Unit I, at core depths between 100 and $70 \mathrm{~cm}$, where ostracods were also present, and likely denotes an excessive deposition of calcite in the core site (Fig. 8). This interval corresponds to a mid-Holocene change of environmental conditions, characterized by increased temperatures, as inferred by the very high correlation $(r=0.94, p=0.002$, $a=95 \%$ ) between the $\mathrm{PC} 2$ scores and $\mathrm{MgO} / \mathrm{CaO}$, a ratio that in small lakes is used as a proxy for paleotemperature (Fritz, 2008). In general, sediments from the warm climatic stages are enriched in $\mathrm{SiO}_{2}, \mathrm{CaO}, \mathrm{Na}_{2} \mathrm{O}, \mathrm{K}_{2} \mathrm{O}$, and $\mathrm{Sr}$ (positive scores on PC2 axis), but depleted in $\mathrm{TiO}_{2}, \mathrm{Al}_{2} \mathrm{O}_{3}, \mathrm{MgO}, \mathrm{Fe}_{2} \mathrm{O}_{3}$, and LOI (negative scores on $\mathrm{PC} 2$ axis), therefore increases of the former during the transition interval between Units II and I (Figs. 5 and $8)$, are interpreted to reflect a transition to warm climatic conditions and calcite dominated sedimentation.

\subsection{Organic geochemistry and stable isotopes}

The TOC, TN, their stable isotopes $\left(\delta^{13} \mathrm{C}_{\text {org }}\right.$ and $\left.\delta^{15} \mathrm{~N}_{\text {tot }}\right)$ and their $\mathrm{C} / \mathrm{N}$ atomic ratio, have been widely used in paleoenvironmental studies from alpine lakes (e.g. Schmidt et al., 2002), and together with the geochemistry PCA, macroinvertebrate and biotic particles results are employed to provide additional evidence of the past environmental changes in Omalos MTP.

Algae have a $\mathrm{C} / \mathrm{N}$ ratio between 4 and 10 , whereas the $\mathrm{C} / \mathrm{N}$ ratio for terrestrial organic matter it is greater than 20 (Meyers et al., 1994). Therefore, increases in $\mathrm{C} / \mathrm{N}$ ratio within sediment profiles have been interpreted to identify periods in a lake's history when sediments received a high proportion of terrestrial organic matter $(\mathrm{C} / \mathrm{N}>10)$, while decreases in $\mathrm{C} / \mathrm{N}$ ratio have been used to identify periods when lake sediments have received a high proportion of algal organic matter (Kaushal and Binford, 1999). The average $\mathrm{C} / \mathrm{N}$ value for Omalos MTP is 6.5, implying a lacustrine origin of the organic matter, but two peaks with $\mathrm{C} / \mathrm{N}$ ratios of 10 and 15 are observed at $150-170 \mathrm{~cm}$ and $46-50 \mathrm{~cm}$, respectively, and which correspond to peaks in the $\delta^{15} \mathrm{~N}$ (Fig. 8). The peaks in $\mathrm{C} / \mathrm{N}$ ratio suggest the establishment of littoral vegetation and a significant contribution of terrestrial organic matter from the catchment. Additionally, the peak of $\mathrm{C} / \mathrm{N}$ ratio at $46-50 \mathrm{~cm}$ of core depth, coincides with the establishment of forest in Omalos MTP catchment, as shown by the Quercus peaks in the pollen diagrams (Ghosn et al., 2010).

The establishment of woodland in the catchment as well as of aquatic vegetation along Omalos MTP shore, is further supported from our findings of biotic particles along this part of the core (Fig. 4). According to our crude chronology, but also by the time constraints depicted by Ghosn et al. (2010), these observations suggest wet conditions in Omalos MTP during the late Holocene $(46-50 \mathrm{~cm}$ of core depth), while the lower peaks $\left(150-170 \mathrm{~cm}\right.$ of core depth) of $\mathrm{C} / \mathrm{N}$ and $\delta^{15} \mathrm{~N}$, 

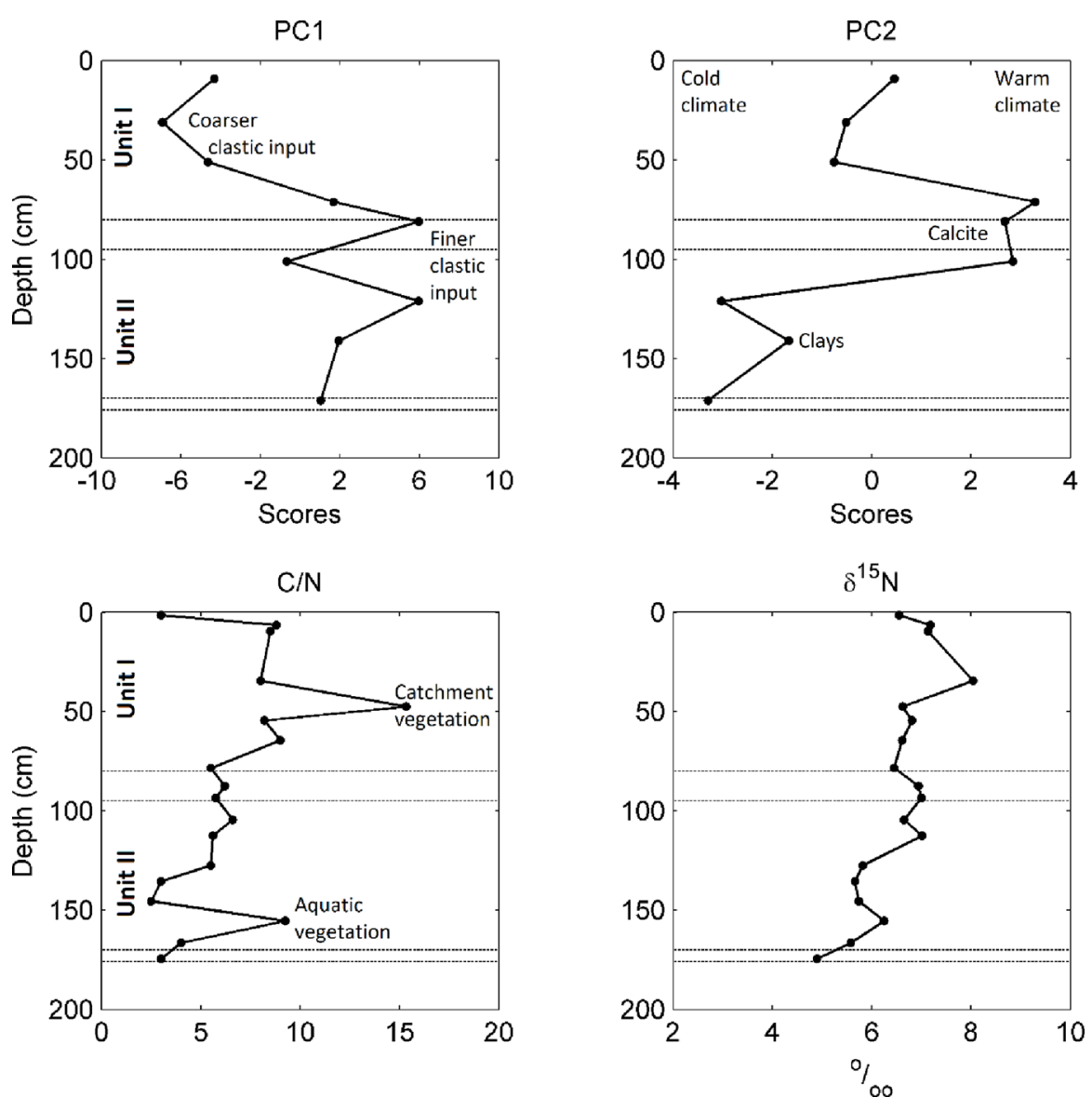

Fig. 8. Downcore variations of the $\mathrm{PC} 1$ and $\mathrm{PC} 2$ scores, with organic paleoenvironmental proxies $\left(\mathrm{C} / \mathrm{N}\right.$ and $\left.\delta^{15} \mathrm{~N}\right)$ measured in Omalos $\mathrm{MTP}$. Dashed lines correspond to the core base $(176-170 \mathrm{~cm})$ and middle $(96-80 \mathrm{~cm})$ dated sediment layers at 16.7 and $4.7 \mathrm{cal}$. ka BP, respectively.

likely coincide with establishment of aquatic vegetation under wet conditions that occurred during the Lateglacial. Organic matter $\delta^{13}$ Corg values (not shown here), were not measured throughout the core, but demonstrate small variations between $-21.8 \%$ and $-25.9 \%$ with an average value of $-23.5 \%$. The highest values $(-21.8 \%$ o occur at the base of the core, while more depleted values correspond to increases in the $\mathrm{C} / \mathrm{N}$ ratio, coherent with changes in the organic matter pool from terrestrial sources.

\section{Discussion}

The Last Glacial Maximum (LGM) conditions in eastern Mediterranean have been characterized by lower than present Sea Surface Temperatures (SST's) by $4{ }^{\circ} \mathrm{C}$, while regional climatic reconstructions suggest the existence of small glaciers in Lefka Ori (Kuhlemann et al., 2008). The low SST's during the LGM, resulted in less available moisture for the establishment of vegetation and the formation of a temporary pond in the highlands of Crete is questionable, but the increasingly warm and moist conditions, occurred since the onset of the Lateglacial, resulted to the gradual deglaciation of Lefka Ori glaciers (Kuhlemann et al., 2008). This, may have led to the gradual filling of Omalos MTP, to the establishment of aquatic vegetation and to increased endogenic sedimentation of clay silicates, as inferred from the peak of $\mathrm{C} / \mathrm{N}=9.2$, the low $\delta^{13} \mathrm{C}(-23 \%)$ values and the increase of PC2 scores between 165 and $140 \mathrm{~cm}$ of core depth (Fig. 8). This warm and relatively wet interval of the Omalos MTP sediment sequence, finds a good representative in the Bølling/Allerød (B/A) warm period that started at $\sim 14.7 \mathrm{ka}$ BP (Rasmussen et al., 2006), which in the Aegean Sea was characterized by an $8^{\circ} \mathrm{C}$ increase in SST's and enhanced fluvial inputs (Ehrmann et al., 2007; Gogou et al., 2007). Warm and moist conditions during the B/A period, have been also captured in the sedimentary archives of Istron Bay in eastern Crete (Theodorakopoulou et al., 2012). The variation of PC1 with depth, suggests that the peaks in PC1 scores at 120 and $80 \mathrm{~cm}$ of core depth (Fig. 8), are characterized by the deposition of fine-grained detrital clays under anoxic conditions (low $\mathrm{MnO} / \mathrm{Fe}_{2} \mathrm{O}_{3}$ ratios) and by the lack of littoral and aquatic vegetation $(\mathrm{C} / \mathrm{N}=5.6)$, and most likely correspond to dry periods of the late Lateglacial (Younger Dryas) and the early to mid-Holocene. The early to mid-Holocene (9.0 and $6.5 \mathrm{ka} \mathrm{BP}$ ) pollen record of Lake Kournas is characterized by relative clastic deposition inactivity that is linked to the driest conditions in western Crete during the entire Holocene (Bottema and Sarpaki, 2003).

The most characteristic change in the sedimentary sequence of Omalos MTP inferred from the inorganic and organic geochemical and isotopic changes and faunal and biotic data, is the mid-Holocene $(\sim 4.7 \mathrm{ka} \mathrm{BP})$ change in the 
environmental conditions. The mid-Holocene changes of PC1 and PC2 scores between $100-80 \mathrm{~cm}$ depth, are marked by changes in the lithological composition and the grain-size of Omalos MTP core sediments from $\mathrm{Al}_{2} \mathrm{O}_{3}$ to $\mathrm{SiO}_{2}$-dominated, by the deposition of calcite and by the presence of ostracods, that all together point to a major reorganization of Omalos MTP sedimentation regime. The presence of ostracods and the positive $\mathrm{PC} 2$ scores with high $\mathrm{MgO} / \mathrm{CaO}$ ratios, reflect high temperatures, while low $\mathrm{C} / \mathrm{N}$ ratios and low numbers of fine roots and parts of stems, point to limited aquatic vegetation, which together with the high positive PC1 scores (fine-grained catchment derived sediments), point to a period with the warmest and driest conditions evidenced in Omalos MTP sediment sequence. This warm and dry phase may well represent the " $4.2 \mathrm{kyr}$ mega drought event" that lasted from 4.5 to $4.0 \mathrm{ka}$ BP (Cullen et al., 2000), which had pronounced impacts on the civilizations around the Mediterranean, such as the collapse of the Acadian Empire and of Egyptian Old Kingdom (Cullen et al., 2000; Weiss, 2000; Mayewski et al., 2004; Triantaphyllou et al., 2014).

The interval that followed the mid-Holocene ecosystem disturbance of Omalos MTP, resulted to the deposition of Unit $\mathrm{I}$, which is characterized by increasingly wet and oxidizing conditions of the sediment sequence (negative PC1 scores, higher $\mathrm{MnO} / \mathrm{Fe}_{2} \mathrm{O}_{3}$ values), by higher sedimentation rates, and by the dominance of $\mathrm{SiO}_{2}$ and $\mathrm{K}$-rich silicates in Omalos MTP sedimentation. Also, the increasing $\mathrm{C} / \mathrm{N}$ ratios of Unit $\mathrm{I}$ that peak in core depths between 50 and $40 \mathrm{~cm}(\mathrm{C} / \mathrm{N}>10)$, are in line with the expansion of Quercus forests in the catchment and with the establishment of aquatic (Isoetes) and herbaceous (Allium) vegetation in Omalos MTP (Ghosn et al., 2010). Wetter-than-present conditions for the southern Aegean Sea between 4.0 and $2.0 \mathrm{ka} \mathrm{BP}$, have been confirmed on the basis of regional pollen reconstrunctions and modeling (Peyron et al., 2017), and set a firm physical basis for the observed changes in Omalos MTP sedimentary regime. The negative PC1 scores (increasing $\mathrm{SiO}_{2}$ and decreasing $\mathrm{Al}_{2} \mathrm{O}_{3}$ concentrations) along Unit I can be attributed to the fact that the establishment of catchment woodland and littoral vegetation after $4.7 \mathrm{ka} \mathrm{BP}$, may have intercepted the lateral transport of the finer $\left(\mathrm{Al}_{2} \mathrm{O}_{3}\right.$ rich) fractions from the catchment to the pond, further explaining the observed sediment enrichment in $\mathrm{SiO}_{2}$. We speculate that in addition to the enhanced transport of quartz particles from the catchment, the wet conditions since the midHolocene, likely fostered higher water levels and primary production, and deposition of biogenic $\mathrm{SiO}_{2}$ contributing in this way to the higher sedimentation rates of Unit I. In addition to the detrital and biogenic deposition of $\mathrm{SiO}_{2}$ within Omalos MTP, the increasing trend of $\mathrm{SiO}_{2}$ since the mid-Holocene, can be further explained by the inputs of inorganic $\mathrm{SiO}_{2}$ during episodes of Sahara dust transport, which in western Mediterranean were found to be more frequent and more intense since the mid-Holocene (Ehrmann et al., 2007; Jiménez-Espejo et al., 2014).

\section{Conclusions}

The sedimentary sequence of Omalos MTP in Lefka Ori massif of western Crete, is studied to depict the general past environmental variations since of the main sedimentological and biogeochemical processes during the past 17000 years. Despite the low-resolution sampling and the crude age-depth model that was based on just two radiocarbon dates, some important conclusions are drawn.

- Based on lithological observations the Omalos MTP littoral core is partitioned in two distinct stratigraphic units. The lower stratigraphic unit (Unit II) spans the Lateglacial and the early to mid-Holocene, characterized by low sedimentation rates $(\sim 8 \mathrm{~cm} / \mathrm{ka})$, whereas the upper stratigraphic unit (Unit I) shows a 2-fold increase $(\sim 17 \mathrm{~cm} / \mathrm{ka})$ since the mid-Holocene $(\sim 4.7 \mathrm{ka} \mathrm{BP})$. The geochemical signature of Omalos MTP core Unit II sediments are dominated by the deposition clays and by fine $\mathrm{Al}_{2} \mathrm{O}_{3}, \mathrm{TiO}_{2}, \mathrm{Cr}_{2} \mathrm{O}_{3}$ and $\mathrm{Fe}_{2} \mathrm{O}_{3}$-rich particles under anoxic conditions (low $\mathrm{MnO} / \mathrm{Fe}_{2} \mathrm{O}_{3}$ ratios), in contrast to Unit I which is characterized by a remarkable increase of $\mathrm{SiO}_{2}$ and by the presence of redox sensitive elements $(\mathrm{Mn})$ and by oxic (high $\mathrm{MnO} / \mathrm{Fe}_{2} \mathrm{O}_{3}$ ratios) conditions. The clastic sedimentation in Omalos MTP littoral zone, is mainly driven by allogenic sources from the catchment, but the aeolian and biological contributions in Unit I may have also been a significant contributor to the observed sedimentation rates.

- Based on the results of PCA of the major geochemical compounds and trace elements, Omalos MTP littoral zone sedimentation between 17.0 and $4.7 \mathrm{ka}$ BP took place under dry conditions that limited the transport of sediment from the catchment to the pond. This prolonged dry phase was interrupted during the Bolling/Allerod period (14.7-13.0 ka BP), which in its regional expression was characterized by a remarkable rise in SST's and fluvial inputs in southern Aegean Sea and by in the local scale by the establishment of aquatic vegetation in Omalos MTP.

- A major disturbance in Omalos MTP sedimentation and geochemistry occurred in the mid-Holocene $(\sim 4.7 \mathrm{ka} \mathrm{BP})$ and was characterized by the driest and warmest climatic conditions of Omalos MTP record, attested by the highest positive $\mathrm{PC} 1$ and $\mathrm{PC} 2$ scores and by high $\mathrm{MgO} / \mathrm{CaO}$ ratios, which is a considered a proxy for temperature. More specific, this environmental deterioration was characterized by the transportation of fine $\mathrm{Al}_{2} \mathrm{O}_{3}$-rich sediments from the catchment to the pond, by deposition of calcite and by the presence of ostracods in pond's the littoral zone. The mid-Holocene disturbance of Omalos MTP finds regional evidence across the eastern Mediterranean, with characteristic impacts on well-established human societies, manifested in many studies.

- The late-Holocene evolution of Omalos MTP, took place under increasingly wet conditions and with the gradual establishment of watershed, aquatic and herbaceous vegetation. Enrichment of the littoral sediments in $\mathrm{SiO}_{2}$ can be attributed to multiple factors, such as the interception of the finer $\left(\mathrm{Al}_{2} \mathrm{O}_{3}\right.$-rich) particles from the watershed and littoral vegetation, the deposition of $\mathrm{SiO}_{2}-$ rich Sahara dust, which increased remarkably in the Mediterranean region since the mid-Holocene and the deposition of biogenic silica, during stages of increased moisture that resulted to long hydroperiod and high water levels of Omalos MTP that could have potentially inundated the core location. 
- The variations of the aquatic vegetation cover of Omalos MTP during the Lateglacial and the Holocene, exhibited limited variations with the exception certain peaks, especially during the mid-Holocene $(4.7 \mathrm{ka} \mathrm{BP})$ that coincide with a major disturbance in the core sedimentology and geochemistry. The examined macroinvertebrate and biotic data from the core analysis were not sufficient to estimate Omalos MTP past ecological status in detail, or to permit correlations of past conditions with the present ecological status of the pond, which depends on microhabitat formations (Friday, 1987), as well as the anthropogenic activities in the surrounding area.

- This study is among the first ones to depict paleoenvironmental changes from a sedimentary sequence retrieved from a MTP spanning the Lateglacial and the Holocene. Even though the analyses presented here suffer from low sampling resolution and adequate chronological controls and can only be tentative, the potential of MTPs in reconstructing climatic and environmental conditions is highlighted. Extreme climatic events during the Holocene, like the $4.7 \mathrm{ka}$ BP event recorded in Omalos MTP, appear to have had severe impacts on Mediterranean human societies, including changes in mobility patterns or even a demographic drop mainly due to reduced food supplies (Weiss, 2000; Berger and Guilaine, 2009). Combined studies of high resolution geochemical records from MTPs along with studies of historical and archaeological archives (e.g. Izdebski et al., 2016; Gogou et al., 2016), can provide robust evidence that will shed additional light on the effects of climate variability on human societies over the study area.

\section{References}

Alley RB, Mayewski PA, Sowers T, Stuiver M, Taylor KC, Clark PU. 1997. Holocene climatic instability: a prominent, widespread event 8200 yr ago. Geology 25: 483-486.

Alpert P, Baldi M, Ilani R, et al. 2006. In: Mediterranean Climate Variability, eds. Elsevier, New York-US, pp. 149-177.

Angélibert S, Marty P, Céréghino R, Giani, N. 2004. Seasonal variations in the physical and chemical characteristics of ponds: implications for biodiversity conservation. Aq. Conserv. 14: 439456.

AQEM Consortium, 2002. Manual for the application of the AQEM method. A comprehensive method to assess European streams using macroinvertebrates, developed for the purpose of Water Framework Directive. Version 1.0, February 2002.

Athanasiou M, Bouloubassi I, Gogou A, et al. 2017. Sea surface temperatures and environmental conditions during the "warm Pliocene" interval ( 4.1-3.2 Ma) in the Eastern Mediterranean (Cyprus). Glob Planet Chang 150: 46-57.

Bartzokas A, Lolis CJ, Metaxas CA. 2003. The $850 \mathrm{hPa}$ relative vorticity centers of action for winter precipitation in the Greek area. Int J Climatol 23: 813-828.

Belk D. 1998. Global status and trends in ephemeral pool invertebrate conservation: implications for Californian fairy shrimp. In: Witham CW, Belk D, Ferren WR, Ornduff R, eds. Ecology. Conservation and Management of Vernal Pool Ecosystems, California Native Plant Society, Sacramento, pp. 147-150.
Berger JF, Guilaine J. 2009. The 8200 cal BP abrupt environmental change and the Neolithic transition: a Mediterranean perspective. Quatern Int 200: 31-49.

Bottema S, Sarpaki A. 2003. Environmental change in Crete: a 9000year record of Holocene vegetation history and the effect of the Santorini eruption. The Holocene 13: 733-749.

Cullen HM, De Menocal PB, Hemming S, et al. 2000. Climate change and the collapse of the Akkadian empire: evidence from the deep sea. Geology 28: 379-382.

Dimitriou E, Karaouzas I, Skoulikidis N, Zacharias I. 2006. Assessing the environmental status of Mediterranean temporary ponds in Greece. Int J Lim 42: 33-41.

Dimitriou E, Moussoulis E, Stamati F, Nikolaidis N. 2009. Modelling hydrological characteristics of Mediterranean Temporary Ponds and potential impacts from climate change. Hydrobiologia 634: 195-208, DOI:10.1007/s10750-009-9898-2.

Dudley DW, 1997. Temporary ponds and their invertebrate communities. Aquat ConservMar Freshw Ecosyst 7: 105-117.

Durrieu de Madron X, Guieu C, Sempéré R, Conan P, Cossa D, et al. 2011. Marine ecosystems' responses to climatic and anthropogenic forcings in the Mediterranean. Prog Ocean 91: 97-166.

Ehrmann W, Schmiedl G, Hamman Y, Kuhnt T, Hemleben C, Siebel W. 2007. Clay minerals in Late Glacial and Holocene sediments in northern and southern Aegean Sea. Palaeogeogr. Palaeocl. 249: 36-57.

Engström DR, Wright, HE. 1984. Chemical stratigraphy of lake sediments as a record of environmental change. In: Haworth EY, Lund JWG, eds. Lake sediments and environmental history, Leicester University Press, UK, pp. 11-67.

European Commission DG Environment, 2003. Interpretation manual of European Union habitats - directive. Natura 2000. Nat. Biodiv. 25: 32-33.

Friday EL. 1987. The diversity of macro invertebrate and macrophyte communities in ponds. Freshw Biol 18: 87-104.

Fritz SC. 2008. Deciphering climate history from lake sediments. $J$ Paleolimnol 39: 5-16, DOI:10.1007/s10933-007-9134-x.

Fytrolakis N. 1980. The Geology of Crete Island. PhD Thesis, National Technical University of Athens.

Ghosn D, Vogiatzakis I, Kazakis G, et al. 2010. Ecological changes in the highest temporary pond of western Crete (Greece): past, present and future. Hydrobiol 648: 3-18.

Gogou A, Bouloubassi I, Lykousis V, Arnaboldi M, Gaitani P, Meyers PA. 2007. Organic geochemical evidence of Late Glacial-Holocene climate instability in the North Aegean Sea. Palaeogeogr Palaeocl 256: $1-20$.

Gogou A, Triantaphyllou MV, Xoplaki E, et al. 2016. Climate variability and socio-environmental changes in the northern Aegean (NE Mediterranean) during the last 1500 years. Quat Sci Rev 136: 209-228.

Graham TB. 2002. Survey of aquatic macro invertebrates and amphibians at Wapatki National Monument, Arizona, USA: an evaluation of selected factors affecting species richness in ephemeral pools. Hydrobiologia 486: 215-224.

Grillas P, Gauthier P, Yavercovski N. Perennou C. 2004. Mediterranean Temporary Pools; Vol. 1 issues Relating to Conservation, Functioning and Management. Station biologique de la Tour du Valat, France.

Harris I, Jones PD, Osborn TJ, Lister DH. 2014. Updated highresolution grids of monthly climatic observations - the CRU TS3.10 Dataset. Int J Climatol 34: 623-642, DOI:10.1002/ joc. 3711 . 
Hercman H, Pawlack J. 2012. MOD-AGE: An age-depth model construction algorithm. Quat Geochronol 12: 1-10.

Hughes L. 2000. Biological consequences of global warming: is the signal already apparent? Tr Ecol Evol 15: 56-61.

Izdebski A, Holmgren K, Weiberg E, et al. 2016. Realizing consilience: How better communication between archaeologists, historians and natural scientists can transform the study of past climate change in the Mediterranean. Quat Sci Rev 136: 5-22.

Jakob C, Poizat G, Veith M, Seitz A, Crivelli AJ, 2003. Breeding phenology and larval distribution of amphibians in a Mediterranean pond network with unpredictable hydrology. Hydrobiologia 499: 51-61.

Jiménez-Espejo FJ, García-Alix A, Jiménez-Moreno G. 2014. Saharan aeolian input and effective humidity variations over Western Europe during the Holocene from a high altitude record. Chem Geol 374-375: 1-12.

Kaushal S, Binford MW. 1999. Relationship between C/N ratios of lake sediments, organic matter sources, and historical deforestation in Lake Pleasant, Massachusetts, USA. J Paleolimnol 22: 439-442.

Kouli K, Gogou A, Bouloubassi I, et al. 2012. Late postglacial paleoenvironmental change in the northeastern Mediterranean region: Combined palynological and molecular biomarker evidence. Quatern Int 261: 118-127.

Kuhlemann J, Rohling EJ, Krumrei I, Kubik P, Ivy-Ochs S, Kucera M. 2008. Regional synthesis of Mediterranean atmospheric circulation during the last glacial maximum. Science 321: 1338-1340.

Lake PS, Palmer MA, Biro P, et al. 2000. Global change and the biodiversity of freshwater ecosystems: impacts on linkages between above-sediment and sediment biota. Bioscience 50: 1099-1107.

Lionello P. 2012. The climate of Mediterranean Region. From the Past to the future. Elsevier, Amsterdam.

Marino G, Rohling EJ, Sangiorgi F. 2009. Early and middle Holocene in the Aegean Sea: interplay between high and low latitude climate variability. Quat Sci Rev 28: 3246-3262.

Massi U, Azzaro E, Kyriakopoulos K, Magganas A. 2002. Geochemical features of the "Plattenkalk" series from the Hordaki area (western Crete, Greece). Periodico di Mineral 69: 311-323.

Mayewski PA, Rohling E, Stager CJ, et al. 2004. Holocene climate variability. Quat Res 62: 243-255.

Meyers PA, Leenheer MJ, Eadie BJ, Maule SJ. 1994. Organic geochemistry of suspended and settling particulate matter in Lake Michigan. Geochem Cosmochim Acta 48, 443-452.

Nicolet P, Biggs J, Fox G. 2004. The wetland plant and macroinvertebrate assemblages of temporary ponds in England and Wales. Biol Conserv 120: 261-278.

Nihlén T, Mattson J, Rapp A, Gagaoudaki C, Kornaros G, Papageorgiou J. 1995. Monitoring of Sahara dust fallout in Crete and its contribution to soil formation. Tellus 47B: 365-374.

Peyron O, Combourieu-Nebout N, Brayshaw D. 2017. Precipitation changes in the Mediterranean basin during the Holocene from terrestrial and marine pollen records: a model-data comparison. Clim Past 13: 249-265.

Poff NL, Brinson MA, Day JW. 2002. Aquatic ecosystems and global climate change: potential impacts on inland freshwater and coastal wetland ecosystems in the United States. PEW Center on Global Climate Change, Arlington, VA. Available from: www.pewclimate. org.

Ramsar Convention Secretariat, 2002. Resolution VIII.33. Guidance for identifying, sustainably managing, and designating temporary pools as Wetlands of International Importance. http://www.ramsar. org/
Rasmussen SO, Andersen KK, Svensson AM. 2006. A new Greenland ice core chronology for the last glacial termination. $J$ Geophys Res 111: D06102, DOI:10.1029/2005JD006079.

Reimer PJ, Baillie MGL, Bard E, et al. 2004. IntCal04 terrestrial radiocarbon age calibration, 0-26 cal kyr BP. Radiocarbon 46: $1029-1058$.

Rhazi L, Grillas P, Tan Ham L, Khyari DEL. 2001. The seed bank and the between years dynamics of the vegetation of a Mediterranean temporary pool (NW Morocco). Ecologia Mediterr 27: 69-88.

Rhazi M, Grillas P, Charpentier A, Médail F. 2004. Experimental management of Mediterranean temporary pools for conservation of the rare quillwort Isoetes setacea. Biol Conserv 118: 675-684.

Richter D, Krahl J, Kaufmann G, Kozur H, Förster O, Heinritzi F. 1983. Neuedatenzur Bi-ostratigraphie und zurtektonischenLagerung der Phyllit-Gruppe und der Trypali-Gruppe auf der Insel Kreta (Griechenland). Geol Rundsch 72: 1147-1166.

Rohling EJ, Mayewski PA, Abu-Zied RH, Casford JSL, Hayes A. 2002. Holocene atmosphere-ocean interactions: records from Greenland and the Aegean Sea. Clim Dynam 18, 587-593.

Schmidt R, Koinig KA, Thompson R, Kamenik C, 2002. A multi proxy core study of the last 7000 years of climate and alpine landuse impacts on an Austrian mountain lake (Unter Landschitzsee, Niedere Tauern). Palaeogeogr Palaeocl 187: 101-120.

Spencer ML, Blaustein S, Schwartz S, Cohen JE. 1999. Species richness and the proportion of predatory animal species in temporary pools, relationship with habitat size and permanence. Ecol Lett 2: 157-166.

Stamati F, Nikolaidis N, Dimitriou E, Koussouris T. 2008. Hydrogeochemical aspects of Mediterranean Temporary Ponds in Western Crete. J Environ Qual 37: 164-173.

Stamatakis M, Anastasatou M, Tsoutsia A, Petrakis S, Kapsimalis V, et al. 2015. Quality factors concerning possible exploitation of Marine Aggregates in NW Crete Island inner shelf. In: Proceedings of 11th Oceanographic Symposium, Mytilene, Greece, pp. 10811084.

Stuiver M, Reimer PJ, Reimer RW. 2005. CALIB 6.1.1. http://calib.org Styllas MN, Ghilardi M. 2017. Early- to mid-Holocene paleohydrology in northeast Mediterranean: the detrital record of Aliakmon River in Loudias Lake, Greece. The Holocene 27: 1487-1498.

Styllas MN, Schimmelpfennig I, Ghilardi M, Benedetti L. 2016. Geomorphologic and paleoclimatic evidence of Holocene glaciation on Mount Olympus, Greece. The Holocene 26: 709-721.

Tachet H, Richoux P, Bournard M, Usseglio-Polatera P. 2010. Invertébrés d'Eau Douce, Systématique, Biologie, Ecologie. Paris, eds. CNRS.

Ten Veen JH, Meijer PT. 1999. Late Miocene to recent tectonic evolution of Crete (Greece): geological observations and model analysis. Tectonophysics 298: 191-208.

Theodorakopoulou K, Pavlopoulos K, Athanassas CD, Zacharias N. 2012. Sedimentological response to Holocene climate events in Istron area, Gulf of Mirabello, NE Crete. Quat Int 266: 62-73, DOI:10.1016/j.quaint.2011.05.032.

Triantaphyllou MV, Ziveri P, Gogou A, et al. 2009. Late Glacial Holocene climate variability at the south-eastern margin of the Aegean Sea. Mar Geol 266: 182-197.

Triantaphyllou MV, Gogou A, Bouloubassi I. 2014. Evidence for a warm and humid Mid-Holocene episode in the Aegean and northern Levantine Seas (Greece, NE Mediterranean). Reg Environ Change 14: 1967-1712, DOI:10.1007/s10113-013-0495-6.

Von Eynatten H, Tolosana-Delgado R, Karius V. 2012. Sediment generation in modern glacial setting: Grain-size and source-rock control on sediment composition, Sediment Geol 280: 80-92. 
Vitousek PM, 1994. Beyond global warming: ecology and global change. Ecology 75: 1861-1876.

Wallace ID, Wallace B, Philipson GN. 1990. A key to the case-bearing larvae of Britain and Ireland. Freshwater Biological Association. Scientific Publication No 51, Series Ed. Elliot, J. M.

Warwick NWM, Brock MA. 2003. Plant reproduction in temporary wetlands: the effects of seasonal timing, depth, and duration of flooding. Aquat Bot 77: 153-167.

Weber ER, Braunitzer G, Kleinschmidt T. 1985. Functional multiplicity and structural correlations in the hemoglobin system of larvae of Chironomus thummi thummi (insecta, diptera): $\mathrm{Hb}$ components CTT I, CTT II $\beta$, CTT III, CTT IV, CTT VI, CTT VIIB, CTT IX and CTT X. Comp. Biochem Physiol Part B: Comp Biochem 80: 747-753.

Weiss H. 2000. Beyond the Younger Dryas: collapse as adaptation to abrupt climate change in ancient West Asia and the Eastern
Mediterranean. In: Bawdon G, Reycraft RM, eds. Environmental Disaster and the Archaeology of Human Response, Maxwell Museum of Anthropology, Albuquerque, pp. 63-74.

Wellborn G, Skelly D, Werner E. 1996. Mechanisms creating community structure across a freshwater habitat gradient. Ann Rev Ecol Sys 27: 337-363.

Williams DD. 1997. Temporary ponds and their invertebrate communities. Aq Conserv 7: 105-117.

Xoplaki E, Luterbacher J, Burkard B, Patrikas I, Maheras P. 2000. Connection between the large scale $500 \mathrm{hPa}$ geopotential height fields and rainfall over Greece during wintertime. Clim Res 14: $129-146$.

Zacharias I, Dimitriou E, Dekker A, Dorsman E. 2007. Overview of temporary ponds in the Mediterranean region: threats, management and conservation issues. $J$ Environ Bio 28: 1-9.

Cite this article as: Styllas M, Dimitriou E, Gritzalis K, Koutsodimou M, Karaouzas I, Skoulikidis N, Gogou A. 2018. Mid-Holocene changes in the geochemical and biotic conditions of an aquatic ecosystem, in Eastern Mediterranean. Ann. Limnol. - Int. J. Lim. 54: 21 